\title{
Research on the Translation of Clothing Trademark Names Based on Cultural Features
}

\author{
Dan ZHOU ${ }^{1,}$, , Jun YIN $^{2, b}$ * \\ ${ }^{1}$ School of Foreign Languages, Wuhan Textile University, Wuhan, 430073, China \\ ${ }^{2}$ Wuhan Textile University, Wuhan, 430073, China \\ aemail:zhoudan@wtu.edu.cn:, bemail: 12408113@qq.com
}

Key words: clothing trademark names; corpus; cultural features; translation strategies

\begin{abstract}
The translation of clothing trademark names, as an intercultural activity, is influenced by many factors like language, history, culture and aesthetic. To elaborate on the importance of cultural features in the translation of clothing trademark names as well as translation strategies, this paper creates a mini-corpus covering 200 famous trademark names usually reported by the world well-known fashion magazines like VOGUE, ELLE, FASHION and analyzes their origins as well as their cultural connotation. On this study, we conclude that the translation of clothing trademark is a dynamic and creative activity instead of a mechanical and stereotypical one.
\end{abstract}

\section{Introduction}

Driven by the rapid development of economic globalization and international trade, the trade between clothing trademarks at home and abroad is developing fast, which attaches great importance to the translation of these trademarks. [1] It is well known that the translation of clothing trademark plays an increasingly important role in clothing sales since it is the core of trademark. [2] Nowadays, the translation of clothing trademark names is not simply an intercultural activity any more. It becomes a tool serving economy. Thus, this paper attempts to empirically analyze the origins and cultural features of the selected clothing trademark names and accordingly to conclude some effective translation strategies.

\section{Methodology}

This paper creates a mini-corpus covering 200 top trademark names usually reported by the world well-known fashion magazines like VOGUE and ELLE in America and FASHION in China. All the trademark names in this corpus come from FASHION and some famous clothing websites. [3]Based on the comparative analysis of the origins and translation methods of these selected trademarks, the author adopts both the qualitative and quantitative method from three aspects, i.e. origins, cultural features and translation methods.

\section{A. Word-Formation Ways of Clothing Trademarks}

Usually, the origins of most English words can provide their meaning and form with formation rules which reversely reflect their evolution process. Accordingly, we find that there are mainly six word-formation ways of clothing trademarks as follows. 
Table 1: Origins of Clothing Trademark Names

\begin{tabular}{|c|l|l|}
\hline word-formation ways of trademarks & number & ratio \\
\hline name of the founder & 144 & $72 \%$ \\
\hline abbreviations & 20 & $10 \%$ \\
\hline new meaning of existing words & 18 & $9 \%$ \\
\hline characters in the story & 8 & $4 \%$ \\
\hline combination of words and number & 6 & $3 \%$ \\
\hline loanwords & 4 & $2 \%$ \\
\hline total number & & $100 \%$ \\
\hline
\end{tabular}

According to Table 1, we can conclude that the ratio of naming trademarks the name of their founders, up to $72 \%$, is the highest which is followed by the ratio of abbreviations and the ratio of new meanings of existing words, respectively reaching to $10 \%$ and $9 \%$.

\section{Cultural Features of Trademark Names}

Language and culture interact with each other. To be specific, language reflects culture while culture relies on language. [4]The trademark has been closely related with culture since its emergence and gradually develops its own personality -- brand personality. [5]Generally speaking, each clothing trademark name has its own origins which reflect their corresponding culture. Thus, a good grasp of the origins and translation of trademark names is theoretically and practically important for the understanding of different cultures. According to the corpus, we find that the cultural feature are mainly shown in the following six aspects,.

\section{A. Individualism -- Name of Certain Characters}

In western countries, people always advocate individualism and individual value. Accordingly, many companies incline to name their trademarks the name or first name of certain characters. [6] It not only shows their respect and commemoration to the founder, but also reflects the value of individualism peculiar to western countries. For instance, the worldwide famous sportswear trademark Adidas actually originates from the founder's name -- Adi Dassler. It is the same with Dior, Cucci, Buberry.

\section{B. Globalization -- Loanwords}

The rapid development of economic globalization and intercultural communication promotes the introduction of foreign trademark names. For clothing trademark names, the decrease of loanwords not only promotes the spread of brand culture, but also shifts the trademark names from localization to globalization. In the mini-corpus we created, we find that only two names are loanwords. [7] That means, trademark names begin to take the form of English, a global language, instead of kinds of local languages. For instance, the name of “安踏”, a famous sportswear trademark in China, is simply translated as"ANTA"in English and "mother of the earth" in Greek which means tolerance and selflessness. It is the same with some famous domestic trademarks like “李宁”, “森马”, which are respectively translated as Li Ning, Semir.

\section{Simplification -- Abbreviations}

Trademark names are considered to be simple and concise so as to be identified, remembered and spread from mouth to mouth. Psychologically, the trademark will be hard to be remembered and recognized once the total number of their letters is higher than 8. Economically, since a trademark is a walking advertisement, the more difficult the name to be spread, the higher the 
publicity cost. According to the mini-corpus we create, we find that more than $80 \%$ of their letter number is fewer than 8 and the ratio of abbreviations is up to $10 \%$.

\section{Allusion and Historic Feature-- Characters in the Story}

The western culture mainly originates from Greco-Roman myths. That means, most western works including clothing trademark names originate from those myths. [8]For example, the worldwide famous trademark Nike from America actually comes from the goddess of victory -Nike. And the famous domestic trademark JOEONE is related with a historical story. In Tang dynasty, nine sons of a family with its first name Lin all obtained Tien Si (a person passed all three examinations held by the government) and were all appointed as provincial governor. The Chinese pronunciation of JOEONE is actually the meaning of "nine provincial governors". Based on this inspiring story, it satisfies Chinese parents' earnest expectations for their children and greatly enhances its reputation. It is the same with some other clothing trademarks like Triumph, Zara, Bally.

\section{E. Fashion -- Combination of Words and Numbers}

Fashion is the core of clothing while clothing is the carrier of fashion. To constantly keep its appealing and customers' interest, trademark names should stay current with fashion and keep innovation all the time. The combination of words and numbers is a good way following the current fashion. For instance, a famous trademark of casual wear named $\mathrm{H} 2 \mathrm{O}$ among which $\mathrm{H} 2$ means Healthy and Happy while O means Open. It not only presents its avocations of health and happiness which psychologically satisfy most customers, but also keeps pace with the current fashion. What's more, the combination of words and number is consistent with the fast-pace life, personification, diversity and internationalization in the modern society. It is the same with $361^{\circ}$,ITISF4, G2000.

\section{F. Popularization -- New Meanings of Existing Words}

With the rapid development of economy, brand clothing is closely involved in people's daily life. And new meanings of existing words emerge rapidly, which shows the popularization of clothing trademarks. It will better spread these words among the public. The trademark names like Mango, Playboy and Lily are typical examples.

\section{Strategies of Translating Clothing Trademark Names}

EA. Gutt, proposer of Relevance Theory of Translation, insists that translation, as a special kind of communication, should adhere to the basic principles of communication and should bridge author's intending and readers' expectations. Therefore, to better serve and promote clothing, translators should not only obey the Relevance Theory, but also take its distinctive features into consideration when translating clothing trademark names. By now, four strategies including literal translation, liberal translation, transliteration and zero translation are commonly adopted in the translation of clothing trademark names. Most translation strategies and methods are closely related with the word formation and corresponding culture.

\section{Conclusion}

After analyzing the origins, corresponding cultural features and translation strategies, we conclude that clothing trademark names always have their peculiar origins mainly including name of the founder, abbreviations, new meanings of existing words, characters in the story, combination of words and numbers and loanwords. All these origins perfectly reflect their brand culture and 
make their translation easily to understand. Besides, the translation of trademark names should also take full account of the market language, cultural features and customers' psychological needs in that they present a company's culture and social image and directly affect their sales in the market. Thus, the translation of clothing trademark names should not only present the features and functions of product, but also integrate into the target market so as to improve their market competitiveness.

\section{Acknowledgement}

In this paper, the research was sponsored by Foundation of Science and Technology Department of Hubei Province (湖北省技术创新专项软科学项目资助; Project No. 2016ADC078) , Foundation of Hubei Educational Committee(Project No. 2016GB036), and Foundation of Wuhan Textile University (Project No. 163092; No. 163053).

\section{References}

[1]A Roadmap for Branding in Industrial Markets. Frederick E Webster, Jr,Kevin L Keller. Journal of Brand Management . 2004

[2] Consumers and Their Brands: Developing Relationship Theory in Consumer Research. Fournier Susan. The Journal of Consumer Research .

[3]The secret to a fashion advantage is brand orientation. Kerrie Bri?dson,Jody Evans. International Journal of Retail \& Distribution Management . 2004

[4] Conceptualizing, Measuring, and Managing Customer-based Brand Equity. Kevin Lane Keller. Journal of Marketing . 1993

[5]Revenue Premium as an Outcome Measure of Brand Equity. Ailawadi,Kusum L.Lehmann,Donald R.,Neslin,Scott A. Journal of Marketing . 2003

[6]Brand Valuation. J.Lindemann. Brands and Branding . 2003

[7] The Effect of Consumer-Based Brand Equity on Firms' Financial Performance. Kim H,Kim W. G. Journal of Consumer Marketing . 2003

[8]Brand Management: What Next?. Shamoon, Sumaira,Saiqa Tehseen. Interdisciplinary Journal Of Contemporary Research In Business . 2011 